\title{
QUEEN'S
UNIVERSITY
BELFAST
}

\section{Performance of a field-scale biological permeable reactive barrier for in-situ remediation of nitrate-contaminated groundwater.}

Gibert, O., Assal, A., Devlin, H., Elliot, T., \& Kalin, R. M. (2019). Performance of a field-scale biological permeable reactive barrier for in-situ remediation of nitrate-contaminated groundwater. Science of the Total Environment, 659, 211. https://doi.org/10.1016/j.scitotenv.2018.12.340

Published in:

Science of the Total Environment

Document Version:

Peer reviewed version

Queen's University Belfast - Research Portal:

Link to publication record in Queen's University Belfast Research Portal

\section{Publisher rights}

Copyright 2019 Elsevier.

This manuscript is distributed under a Creative Commons Attribution-NonCommercial-NoDerivs License

(https://creativecommons.org/licenses/by-nc-nd/4.0/), which permits distribution and reproduction for non-commercial purposes, provided the author and source are cited.

\section{General rights}

Copyright for the publications made accessible via the Queen's University Belfast Research Portal is retained by the author(s) and / or other copyright owners and it is a condition of accessing these publications that users recognise and abide by the legal requirements associated with these rights.

Take down policy

The Research Portal is Queen's institutional repository that provides access to Queen's research output. Every effort has been made to ensure that content in the Research Portal does not infringe any person's rights, or applicable UK laws. If you discover content in the Research Portal that you believe breaches copyright or violates any law, please contact openaccess@qub.ac.uk. 
This is a post-print version of the published paper in Science of the Total Environment, 659 (2019) 211-220. Published Online 24/12/18. https://doi.org/10.1016/j.scitotenv.2018.12.340. A Share Link is available until 17 February 2019 via https://authors.elsevier.com/c/1YJARB8ccgidB.

PERFORMANCE OF A FIELD-SCALE BIOLOGICAL PERMEABLE REACTIVE BARRIER FOR IN-SITU REMEDIATOIN OF NITRATE-CONTAMINATED GROUNDWATER

8 a Chemical Engineering Department, EEBE, Universitat Politècnica de Catalunya (UPC)-

9 BarcelonaTech, c/Eduard Maristany 10-14, Barcelona 08019, Spain.

$10 \mathrm{~b}^{\mathrm{b}}$ Barcelona Research Center in Multiscale Science and Engineering, EEBE, Universitat

11 Politècnica de Catalunya (UPC)-BarcelonaTech, c/Eduard Maristany 10-14, Barcelona 08019, 12 Spain.

$13{ }^{\mathrm{c}}$ Department of Civil and Environmental Engineering, University of Strathclyde, 75 Montrose 14 St., Glasgow G1 1XJ, United Kingdom.

$15{ }^{\mathrm{d}}$ School of Natural \& Built Environment, Queen's University Belfast, Stranmillis Rd, Belfast 16 BT9 5AG, Antrim, United Kingdom

* corresponding author: Oriol Gibert (email: oriol.gibert@upc.edu)

\section{Abstract}

We report the performance of a field-scale permeable reactive barrier (PRB) for the biological treatment of nitrate-contaminated groundwater. The reactive material of the PRB consisted of a mixture of gravel and mulch as a carbon source for denitrifying bacteria. The PRB was equipped with a delivery system that allowed injecting $\mathrm{NO}_{3}{ }^{-}$at controlled rates from the surface directly into the up-gradient layer of the PRB. This way, $\mathrm{NO}_{3}{ }^{-}$concentration entering the PRB 
was varied (from 1 to $530 \mathrm{mg} / \mathrm{L}$ ) with the purpose of evaluating the ultimate efficiency of the PRB under different $\mathrm{NO}_{3}^{-}$loadings. The $\mathrm{PRB}$ was successful at removing $\mathrm{NO}_{3}^{-}$from

30 groundwater at inlet concentrations up to $280 \mathrm{mg} / \mathrm{L}$ (with $\mathrm{NO}_{3}{ }^{-}$removal percentages $\geq 97 \%$ ).

31 Monitoring of groundwater at different depths within the PRB provided evidence that $\mathrm{NO}_{3}{ }^{-}$

32 underwent denitrification preferably at the deepest part of the PRB, where more favourable

33 reducing conditions were achieved. Among the shortcomings of the PRB were the fluctuations

34 of groundwater fluxes caused by intense rainfalls during the study period, although they

35 generally did not pose concern for the denitrification capacity of the PRB. Emission fluxes of 36 gases $\left(\mathrm{CO}_{2}, \mathrm{CH}_{4}\right.$ and $\left.\mathrm{N}_{2} \mathrm{O}\right)$ from the PRB to the atmosphere were also measured. The results are 37 finally compared with the few others reported existing PRBs for nitrate-contaminated 38 groundwater worldwide.

40 Keywords: Denitrification, Groundwater contamination, Nitrate, In-situ remediation, $41 \quad$ Permeable reactive barrier

\section{INTRODUCTION} health issue worldwide (Fazal et al., 2003; Rivett et al., 2018). It generally originates from anthropogenic sources, mainly from intensive application of fertilisers and animal manure, from landfill leachates and septic tanks leakages (Della Rocca et al., 2007; Stuart and Lapworth, 2016). $\mathrm{NO}_{3}{ }^{-}$easily percolates into groundwater, through which it can be discharged into surface waterbodies (streams, rivers, lakes) adversely affecting ecosystems (e.g. causing eutrophication)

53 (Addy et al., 2016; Rivett et al., 2018). $\mathrm{NO}_{3}{ }^{-}$concentration exceeding the nominal limit of 50

$54 \mathrm{mg} / \mathrm{L}$ for drinking water set by the World Health Organization have been recorded in numerous 55 aquifers worldwide (Rivett et al., 2008; Huang et al., 2015). Excessive $\mathrm{NO}_{3}{ }^{-}$ingestion from 
polluted drinking waters can induce methemoglobinemia, hypertension, cancers and a number of currently inconclusive health repercussions (Della Rocca et al., 2007). Remediation of groundwater contaminated by $\mathrm{NO}_{3}^{-}$is a matter of active research. Among the available remediation approaches, biological denitrification appears to be the most effective and desirable one (Della Rocca et al., 2007). Denitrification is defined as the dissimilatory biological reduction of $\mathrm{NO}_{3}{ }^{-}$to nitrogen gas $\left(\mathrm{N}_{2}\right)$ through a multistep process, in which $\mathrm{NO}_{3}{ }^{-}$is sequentially converted into nitrite $\left(\mathrm{NO}_{2}{ }^{-}\right)$, nitric oxide $(\mathrm{NO})$, nitrous oxide $\left(\mathrm{N}_{2} \mathrm{O}\right)$ and, finally, harmless nitrogen gas $\left(\mathrm{N}_{2}\right)$ as shown in the following equation:

$$
\mathrm{NO}_{3}{ }^{-} \rightarrow \mathrm{NO}_{2}{ }^{-} \rightarrow \mathrm{NO} \rightarrow \mathrm{N}_{2} \mathrm{O} \rightarrow \mathrm{N}_{2}
$$
of either an organic compound (by heterotrophic bacteria) or an inorganic compound (by autotrophic bacteria). Heterotrophic denitrification, on which most of the denitrification-based treatments rely, can be described by the following overall reaction:

1

$$
5 \mathrm{CH}_{2} \mathrm{O}+4 \mathrm{NO}_{3}{ }^{-} \rightarrow 2 \mathrm{~N}_{2}+5 \mathrm{HCO}_{3}{ }^{-}+2 \mathrm{H}_{2} \mathrm{O}+\mathrm{H}^{+}
$$

where $\mathrm{CH}_{2} \mathrm{O}$ represents a generic organic compound. In subsurface environments, the lack of readily available organic carbon has often been reported as the most common hindrance to denitrification (Jahangir et al., 2012). This limitation explains why, until recently, the use of denitrifying bacteria for groundwater treatment has traditionally been reserved to ex-situ treatments in bioreactors. However, latterly attention has focused on the supply of an external organic substrate in the aquifer itself (in-situ treatment).

One option of applying an organic substrate into the aquifer is through a permeable reactive barrier (PRB). A PRB consists in placing a reactive material across the flow path of contaminated groundwater so that the contaminants can be transformed as groundwater flows through the reactive material (Scherer et al., 2000; Kalin, 2004). The selection of the reactive 
material is crucial: it must be chemically effective to eliminate the target contaminant(s) and must maintain an adequate permeability to ensure flow through the PRB. In a heterotrophic denitrification $\mathrm{PRB}$, the reactive material consists of an organic substrate to stimulate denitrifying activity. PRBs are designed to be passive treatment systems in the sense that, once installed, groundwater typically flows through the reactive zone under its natural hydraulic gradient, and thereby energy input is not needed.

Most of the PRBs currently installed worldwide are based on abiotic processes, and only a small number on biotic processes, mostly for the bioremediation of groundwater contaminated by acid mine drainage (Benner et al., 2002; Gibert et al. 2013), hydrocarbons (McGovern et al., 2002; Gibert et al., 2007) and, as it is the case of the present study, nitrate (Robertson et al., 2008). With regard to the latter case, there is considerable laboratory-based research on promoting denitrification by the addition of organic substrates (Della Rocca et al., 2006; Su and Puls, 2006; Huang et al., 2015; Li et al., 2017). Nevertheless, most of these studies have been performed with configurations (e.g. batch, column and tank tests) and under controlled operational conditions (e.g. constant water composition, constant flow rate, constant temperature, homogeneous reactive materials, biostimulation of denitrifying bacteria) that differ from those in field-scale PRBs, where site weather, geochemistry and hydrology can all fluctuate.

Hence, while lab-studies undoubtedly provide useful information and contribute to a better understanding of denitrification in carbon-amended porous media, their results cannot automatically nor reliably be extrapolated to field-scale PRBs. As highlighted by other researchers (Addy et al., 2016), further research is required, as it is only through accumulated experience at field-scale that such a technology can be successfully applied and tailored to sitespecific conditions.

The aim of this study was to evaluate the ultimate performance of a denitrification PRB, the first of its kind in Europe, over a period of 11 months. An aspect that made this PRB unique is that it was equipped with an injection system that allowed controlled concentrations of $\mathrm{NO}_{3}{ }^{-}$ to be injected into the aquifer directly upgradient of the PRB, providing an opportunity to 
112 evaluate the $\mathrm{NO}_{3}^{-}$removal efficiency of the $\mathrm{PRB}$ under increasing $\mathrm{NO}_{3}^{-}$loadings. From a

113 broader perspective, and given the scarce data within this field, the objective of this study was

114 to contribute to a better understanding of these systems and aid design of future PRBs.

115

116

117 2. MATERIALS AND METHODS

118

119 2.1. Site characterization

120

The site is located on the eastern edge of Ballymena (Northern Ireland), within the

122 relatively flat flood plain of the River Braid. It was used in the past for agricultural purposes

123 until 1998, when the Ballymena Borough Council purchased the site for the Millenium Ecos

124 Centre used to study the local environment.

125 A total of 21 boreholes, aligned in transects approximately perpendicular to the Braid

126 River, were drilled in the study area to provide the site geologic lithology and to allow the

127 installation of piezometers for monitoring the groundwater hydrology and quality (Figure 1). An

128 additional number of 8 boreholes were drilled beyond the study area to yield information on the

129 lithology of the whole site (data not shown). The intrusive works revealed a shallow aquifer

130 over much of the site, which presented a lithology consisting of an upper layer of silt and clay

131 (generally to $1.5 \mathrm{~m}$ below ground level), underlain by a coarse layer (primarily gravel and sand

132 with some silt) ranging in thickness approx. 1.5 to $3 \mathrm{~m}$ below ground level, underlain in turn by

133 a stiff boulder clay (subglacial till) that acts as an aquitard beneath the aquifer due to its low

134 permeability. Measurements of groundwater levels showed that groundwater flows in a

135 southwesterly direction, with groundwater flow lines converging to the river (Figure 1). The

136 mean hydraulic conductivity of the aquifer, based on slug tests, is $2 \mathrm{~m} / \mathrm{d}$, and the mean hydraulic

137 gradient is $0.53 \%$.

138

139 
Figure 1: Map view of the site showing the monitoring well locations and the groundwater flow

164 direction. Dash area corresponds to the denitrification PRB.

165

166

167

168 pollution of the aquifer at the site and that $\mathrm{N}$-species were clearly not of regulatory concern

169

170

171

172

173

174

175 
177

\begin{tabular}{lcc} 
& units & Concentration \\
\hline $\mathrm{pH}$ & & $6.8 \pm 0.5$ \\
$\mathrm{ORP}$ & $\mathrm{mV}$ & $21 \pm 63$ \\
$\mathrm{DO}$ & $\mathrm{mg} / \mathrm{L}$ & $<1$ \\
$\mathrm{Cond}$. & $\mu \mathrm{S} / \mathrm{cm}$ & $270 \pm 112$ \\
$\mathrm{NO}_{3}{ }^{-}$ & $\mathrm{mg} / \mathrm{L}$ & $4.5 \pm 3.5$ \\
$\mathrm{NO}_{2}{ }^{-}$ & $\mathrm{mg} / \mathrm{L}$ & $1.4 \pm 0.8$ \\
$\mathrm{NH}_{4}{ }^{+}$ & $\mathrm{mg} / \mathrm{L}$ & $0.5 \pm 0.3$ \\
$\mathrm{TOC}^{+}$ & $\mathrm{mg} / \mathrm{L}$ & $2.7 \pm 0.9$ \\
$\mathrm{Na}^{+}$ & $\mathrm{mg} / \mathrm{L}$ & $14 \pm 2$ \\
$\mathrm{~K}^{+}$ & $\mathrm{mg} / \mathrm{L}$ & $3 \pm 2$ \\
$\mathrm{Ca}^{2+}$ & $\mathrm{mg} / \mathrm{L}$ & $40 \pm 8$ \\
$\mathrm{Mg}^{2+}$ & $\mathrm{mg} / \mathrm{L}$ & $12 \pm 4$ \\
$\mathrm{Cl}^{-}$ & $\mathrm{mg} / \mathrm{L}$ & $14 \pm 1$ \\
$\mathrm{SO}_{4}{ }^{2-}$ & $\mathrm{mg} / \mathrm{L}$ & $8 \pm 7$ \\
$\mathrm{Alk}^{2}\left(\mathrm{as} \mathrm{CaCO}_{3}\right)$ & $\mathrm{mg} / \mathrm{L}$ & $178 \pm 62$ \\
\hline
\end{tabular}

Table 1: Composition of the groundwater at the Ecos site

The site was chosen as there was $\mathrm{NO}_{3}{ }^{-}$contamination at the site, and therefore the ability for the PRB to naturally exhibit denitrifying potential, and under increasing loads of $\mathrm{NO}_{3}{ }^{-}$in groundwater was ideal for this study. Therefore the proposed PRB was designed to incorporate a controlled delivery system of $\mathrm{NO}_{3}^{-}$to test its denitrification performance at different $\mathrm{NO}_{3}{ }^{-}$loading rates.

\subsection{Design of the PRB}

The design of the PRB was performed according to established guidelines (Gavaskar et al., 1999; Obiri-Nyarco et al., 2014). Briefly, site characterisation allowed setting the location, configuration, orientation and dimensions (width and depth) of the PRB in order to successfully intercept the contaminated plume, while laboratory experiments allowed selecting the most suitable components of the PRB and, with the denitrification kinetics data, determining the required thickness of the PRB to ensure a targeted removal of $\mathrm{NO}_{3}^{-}$. Among the substrates 
194 evaluated in this laboratory study, mulch consisting of hardwood with small amounts of leaves

195 supplied by the local company M. Large Tree Services Ltd (Newtownabbey, Northern Ireland)

196 was the top performing substrate, attaining an overall $\mathrm{NO}_{3}^{-}$removal mostly via denitrification of

$197>96 \%$ in both batch and column systems (Gibert et al. 2008).

198 The PRB was designed as a continuous trench perpendicular to the groundwater flow 199 direction and parallel to the Braid River approximately $13 \mathrm{~m}$ from the riverbank (Figure 1). The 200 vertical position of the PRB was selected in order to be keyed into the underlying clay and to 201 intercept the groundwater in the shallow aquifer. The dimensions were $20 \mathrm{~m} \mathrm{long}, 1.7 \mathrm{~m}$ deep 202 and $1.8 \mathrm{~m}$ thick, and it was positioned 1.5 to 3.2 below the ground level. The excavated trench 203 was backfilled using gabion technology with a mixture of $50 \%(\mathrm{v} / \mathrm{v})$ mulch and gravel (approx. $2045-10 \mathrm{~mm}$ size) previously homogenised (porosity of the mixture approx. 0.30 ) identical to that 205 used in the laboratory experiments (Gibert et al., 2008). Mulch was added as the organic 206 substrate to promote denitrification, while gravel was added to ensure a high permeability 207 within the PRB. Denitrifying bacteria are ubiquitous in groundwater (Rivett et al., 2008), and 208 of the reactive zone to provide a highly permeable zone that facilitated uniform flow of 212 groundwater through the PRB (Figure 2). It is in the upgradient layer of gravel where $\mathrm{NO}_{3}{ }^{-}$was injected. On completion of backfilling, the top of the PRB was covered with excavated material 214 and compacted to limit oxygen diffusion and flow of infiltrating water into the barrier.

215 The $\mathrm{NO}_{3}{ }^{-}$delivery system consisted of two elevated $230 \mathrm{~L}$ tanks (with 1.5 meters of 216 hydraulic head) connected to a drip irrigation system through which site groundwater with 217 variable concentrations of $\mathrm{NO}_{3}^{-}$was continuously injected into the upgradient gravel layer, 218 ultimately through the reactive zone. The injection was accomplished by a row of 22 drip 219 emitters situated along the upgradient gravel layer. The close spacing between the drip emitters 220 was to provide a uniform front of $\mathrm{NO}_{3}^{-}$flowing towards the barrier. This delivery system 221 allowed a precise control of the $\mathrm{NO}_{3}{ }^{-}$loading rate injected into the aquifer by selecting the $\mathrm{NO}_{3}{ }^{-}$ 
concentration within the barrels and controlling the injection rate at ca. $0.1 \mathrm{~L} / \mathrm{min}$ (refilling of

223 barrels approximately every 3 days). A scheme of the drip irrigation system is shown in Figure

2. By using values of groundwater flow rates and injection rates, the expected dilution factor for

$\mathrm{NO}_{3}{ }^{-}$once injected into the upgradient gravel layer was quantified at approx. 10 (this value was later validated by a tracer test).

227

228

229

230

231

232

233

234

235

236

237

238

239

240

241

242

243

244

245

246

247

248

249

250

251

252

253

254

255

256

257

258

259

a) isometric view of the PRB

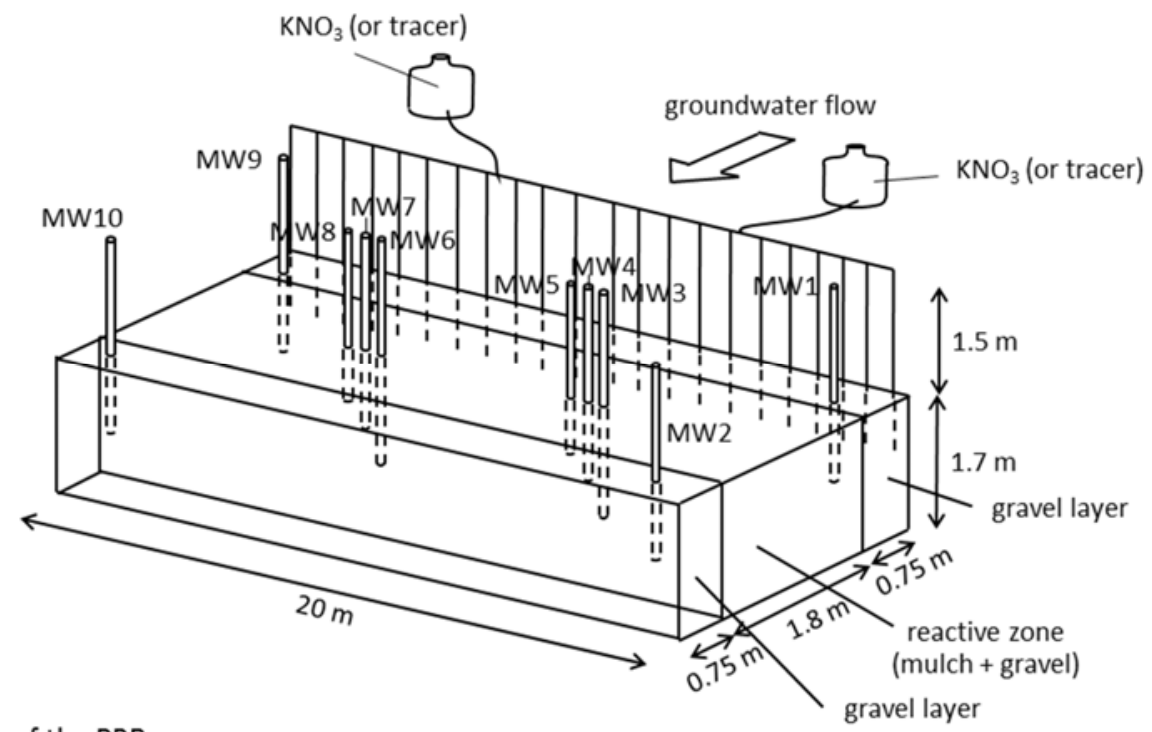

b) aerial view of the PRB

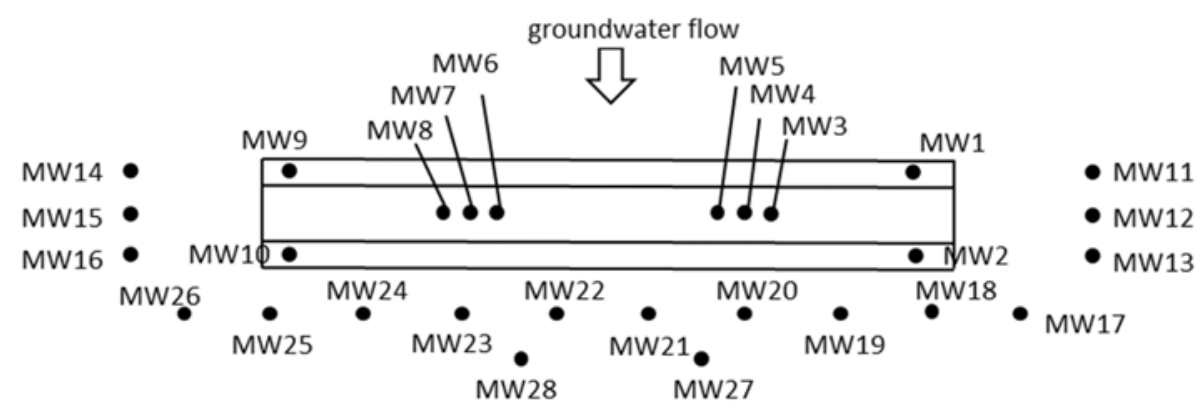

River Braid

Figure 2: Conceptual scheme of the PRB; a) isometric view of the PRB showing the delivery system of $\mathrm{NO}_{3}{ }^{-}$and the position of the monitoring wells within the $\mathrm{PRB}, \mathrm{b}$ ) aerial view of the PRB showing the monitoring well network. 
A monitoring network consisting of 28 wells was installed within and around the PRB to evaluate its performance. Unless otherwise stated the wells were completed in the Gravel

264 Aquifer at $2.5 \mathrm{~m}$ below ground level. As shown in Figure 2, two monitoring wells were installed 265 in the upgradient gravel layer (to monitor the groundwater entering the barrier) and two more in 266 the downgradient gravel layer (to monitor treated groundwater). Two additional sets of 267 monitoring wells were emplaced to monitor groundwater inside the barrier. Both consisted of 268 three nested piezometers with a $0.5 \mathrm{~m}$ slotted screen each, terminated at depths of 2.0, 2.5 and $3.0 \mathrm{~m}$ below ground. Six wells were installed at either side of the PRB and the remaining twelve wells were placed between the PRB and the River Braid (Figure 2b) to assure that water entering the river was satisfying regulatory requirements placed on the research programme.

272

\subsection{Hydraulic PRB validation}

A NaCl tracer test was conducted soon after the installation of the PRB and before any $\mathrm{NO}_{3}{ }^{-}$delivery in order to validate the flow through the PRB and the dilution factor estimated from the initial hydrogeological survey. For that purpose, a solution of $\mathrm{Cl}^{-}(1621 \mathrm{mg} / \mathrm{L}$ as measured) was injected from the barrels into the upgradient gravel layer. Monitoring carried out during the 8 week period of the tracer test showed that: 1) no $\mathrm{Cl}^{-}$was measured at either side of the PRB (MW11 to MW16), proving that groundwater flow direction was perpendicular to the PRB and that no by-pass flow occurred around the PRB, 2) the maximum measured $\mathrm{Cl}^{-}$ concentration in wells in the upgradient gravel layer and within the PRB was $150 \mathrm{mg} / \mathrm{L}$, indicating a dilution factor of 10.8 (which was in close agreement with the dilution factor of 10 estimated from the design based on hydrogeological modelling), and 3) the time needed for the

$285 \mathrm{Cl}^{-}$to travel from the upgradient to downgradient layers (residence time within the PRB) was 14 286 days. All these findings confirmed the design parameters were reflected in the PRB operation as 287 built. 


\section{5. $\mathrm{NO}_{3}^{-}$delivery plan}

The calculated dilution factor $(10.8)$ was used to select $\mathrm{NO}_{3}{ }^{-}$concentration in the barrels that, after dilution, would provide a desired concentration of $\mathrm{NO}_{3}{ }^{-}$entering the PRB.

A stepwise increase of $\mathrm{NO}_{3}{ }^{-}$concentration in barrels was planned in order to investigate

the PRB performance at various $\mathrm{NO}_{3}^{-}$loading rates. Before proceeding with any increment of

$\mathrm{NO}_{3}{ }^{-}$loading rate, action and regulatory oversight was agreed with the Environment Agency of

Northern Ireland. The delivery plan carried out during the study is presented in Figure $3 . \mathrm{NO}_{3}{ }^{-}$

was first spiked into the aquifer with a concentration of $\mathrm{NO}_{3}{ }^{-}$in the barrels of $500 \mathrm{mg} / \mathrm{L}$ (before

dilution by the groundwater flowing through the PRB) for 157 days. The PRB immediately demonstrated the denitrifying ability was effective at removing all $\mathrm{NO}_{3}{ }^{-}$from groundwater during this first phase, and $\mathrm{NO}_{3}{ }^{-}$concentration in the barrels was increased to $5,000 \mathrm{mg} / \mathrm{L}$ until day 206 , when it was further increased to $10,000 \mathrm{mg} / \mathrm{L}$ for the following 49 days. Given that

$\mathrm{NO}_{3}{ }^{-}$removal was maintained $>97 \%$, it was decided to further increase $\mathrm{NO}_{3}{ }^{-}$concentration in barrels to $20000 \mathrm{mg} / \mathrm{L}$ until day 340 .

304

305

306

307

308

309

310

311

312

313

314

315

316

317

318 319

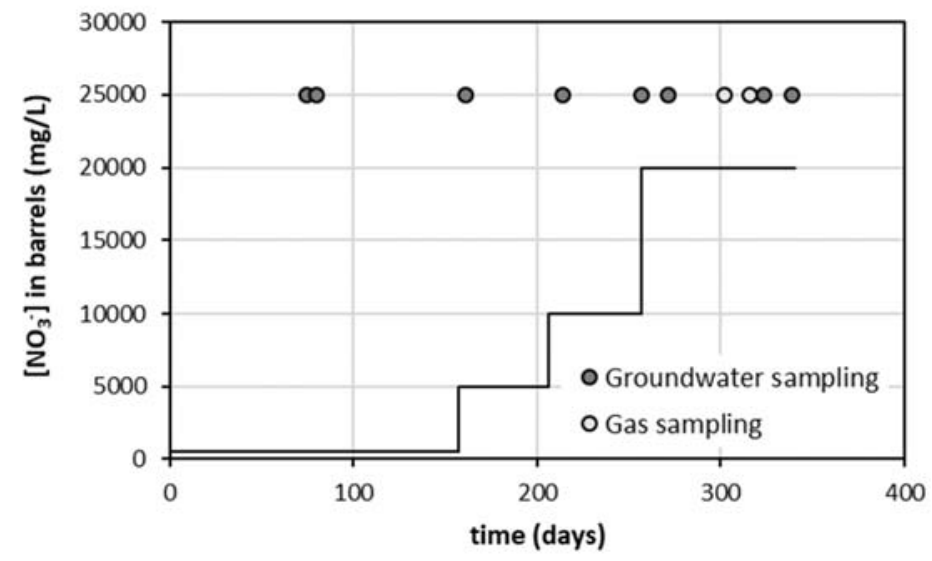

Figure 3: $\mathrm{NO}_{3}{ }^{-}$delivery plan during the operation of the PRB and dates of sampling events 


\subsection{Denitrification quantification}

322

323 We recognized that dilution within the PRB may occur due to changes in flow rates

324 and/or direction of groundwater (caused by e.g. rainfall episodes), and these could bias the

325 interpretation of results. The choice of the nitrate source $\left(\mathrm{KNO}_{3}\right)$ allowed the concentration of

$326 \mathrm{NO}_{3}^{-}$to be normalized with respect to the conservative $\mathrm{K}^{+}$ion. $\mathrm{K}^{+}$was used for the following

327 reasons: (1) it was found to behave conservatively within the mulch/gravel media (not suffering

328 from lateral mechanisms e.g. adsorption) in lab-tests, (2) it presented very low background

329 concentrations in the site groundwater, and (3) it is easy to detect at low concentration. Hence,

$330 \mathrm{NO}_{3}{ }^{-}$and $\mathrm{K}^{+}$were injected together into the PRB in the form of $\mathrm{KNO}_{3}$ (ratio 1:1). Any observed

331 decrease of $\mathrm{NO}_{3}{ }^{-}$concentration as compared to $\mathrm{K}^{+}$concentration would be indicative of $\mathrm{NO}_{3}^{-}$

332 removal due to processes other than simple dilution (e.g. through denitrification).

333 A denitrification factor (DNF) was thus defined as follows:

$$
\mathrm{DNF}=\frac{\left[\mathrm{NO}_{3}^{-}\right]_{\text {out }} /\left[\mathrm{K}^{+}\right]_{\text {out }}}{\left[\mathrm{NO}_{3}^{-}\right]_{\text {in }} /\left[\mathrm{K}^{+}\right]_{\text {in }}}
$$

where subindexes "in" and "out" refer to inlet and outlet of the PRB, respectively. A DNF approaching 0 was indicative of total $\mathrm{NO}_{3}{ }^{-}$removal, whereas a DNF tending to 1 was indicative of no removal at all (and that any observed decrease in $\mathrm{NO}_{3}{ }^{-}$concentration was due to dilution).

340

341

\subsection{Groundwater sampling and chemical analysis}

342

Groundwater was collected from monitoring wells for chemical analysis. Each well was

344 purged using a submersible pump (whales minipurger, flowrate $10 \mathrm{l} / \mathrm{min}$ ) for about 1 minute 
prior to sampling (representing over 5 well volumes). River water from upstream and

346 downstream of the PRB was also sampled using the same submersible pump.

347 Groundwater analysis comprised the determination of $\mathrm{pH}$, nitrate $\left(\mathrm{NO}_{3}^{-}\right)$, nitrite $\left(\mathrm{NO}_{2}^{-}\right)$, 348 ammonium $\left(\mathrm{NH}_{4}^{+}\right)$, dissolved organic carbon (DOC) and major cations and anions $\left(\mathrm{K}^{+}, \mathrm{Na}^{+}\right.$,

$\left.349 \mathrm{Ca}^{2+}, \mathrm{Mg}^{2+}, \mathrm{Cl}^{-}, \mathrm{SO}_{4}{ }^{2-}\right)$. After collection, samples were immediately stored at $4^{\circ} \mathrm{C}$ and shipped to 350 an ISO17025 accredited laboratory under the United Kingdom Schemes (UKAS) (Alcontrol 351 Laboratories) for analysis within 48 hours in order to avoid any post sampling microbial 352 degradation. A total of nine campaigns were carried out for groundwater analysis, as shown in 353 Figure 3.

354 The Kone analyser was used for the analysis of $\mathrm{NO}_{3}^{-}$and $\mathrm{NO}_{2}{ }^{-}$(APHA Method $\left.4500 \mathrm{H}\right)$ 355 (AWWA/APHA, 1999), $\mathrm{NH}_{4}{ }^{+}$(BS 6068: Part 2.11:1984) (BSI, 1984), $\mathrm{SO}_{4}{ }^{2-}$ (APHA Method 356 4500E) (AWWA/APHA, 1999) and $\mathrm{Cl}^{-}$(modified US EPA Method $325.1 \&$ 325.2) (USEPA, 357 1983). $\mathrm{pH}$ was analysed using a GLpH pHmeter (BS 1377 Method) (BSI, 1984). DOC was 358 analysed by combustion according to APHA Method 5310 (AWWA/APHA, 1999). Cations $\mathrm{Na}^{+}$ 359 and $\mathrm{K}^{+}$were analysed by ICP-OES according to APHA Method 3111 (AWWA/APHA, 1999) 360 while $\mathrm{Ca}^{2+}$ and $\mathrm{Mg}^{2+}$ by ICP-MS according to APHA Method 3125B (AWWA/APHA, 1999). 361 The limits of detection for these analytes (in mg/L) were $0.3\left(\mathrm{NO}_{3}^{-}\right), 0.05\left(\mathrm{NO}_{2}{ }^{-}\right), 0.2\left(\mathrm{NH}_{4}{ }^{+}\right), 3$ $362\left(\mathrm{SO}_{4}^{2-}\right), 1\left(\mathrm{Cl}^{-}\right), 2(\mathrm{DOC}), 0.2\left(\mathrm{~K}^{+}\right.$and $\left.\mathrm{Na}^{+}\right), 0.1\left(\mathrm{Ca}^{2+}\right.$ and $\left.\mathrm{Mg}^{2+}\right)$.

\subsection{Gases sampling and chemical analysis}

In a denitrification system, $\mathrm{NO}_{3}{ }^{-}$is ideally converted totally to $\mathrm{N}_{2}$ according to reaction

367 (1). However, incomplete denitrification may result in the accumulation of intermediate species, 368 e.g. $\mathrm{NO}$ and $\mathrm{N}_{2} \mathrm{O}$. Moreover, degradation of organic matter in anaerobic conditions (either by 369 denitrifying bacteria or other bacteria also present in the system) can lead to the accumulation of 370 carbon dioxide $\left(\mathrm{CO}_{2}\right)$ and methane $\left(\mathrm{CH}_{4}\right)$. These gases, together with $\mathrm{N}_{2} \mathrm{O}$ are known to be

371 potent greenhouse gases of major environmental concern, and in this case by the regulator on 372 site. In fact, $\mathrm{N}_{2} \mathrm{O}$ and $\mathrm{CH}_{4}$ exhibit a global warming potential for a 100 -year time horizon 298 
and 25 times greater, respectively, than that of $\mathrm{CO}_{2}$ (IPCC, 2007). In subsurface systems, gases

374 can be emitted via upward diffusion from groundwater through the unsaturated zone to the 375 atmosphere (Jurado et al., 2017). For this reason, emissions of $\mathrm{CO}_{2}, \mathrm{CH}_{4}$ and $\mathrm{N}_{2} \mathrm{O}$ were 376 measured using the closed chamber method (Hensen et al., 2012). The chamber consisted of a 377 plastic box $(31 \times 31 \mathrm{~cm})$ inserted into the soil above the PRB to a depth of $5 \mathrm{~cm}$. The enclosure 378 surface area was $0.0961 \mathrm{~m}^{2}$ and the created headspace volume $0.0115 \mathrm{~m}^{3}$. Gas from the 379 headspace of the chamber was pumped continuously through PTFE tubing connected to the 380 chamber for a 70-min collection period and contents of $\mathrm{CO}_{2}, \mathrm{CH}_{4}$ and $\mathrm{N}_{2} \mathrm{O}$ were analysed using a portable MCERTS accredited FTIR multiparameter gas analyser (Gasmet DX 4030).

382 To further elucidate the generation of $\mathrm{CO}_{2}, \mathrm{CH}_{4}$ and $\mathrm{N}_{2} \mathrm{O}$ and their potential for upward 383 migration and discharge to the atmosphere, these gases were measured in the headspace of each 384 of the three nested wells at different depths within the PRB. Wells were sealed with gas tight 385 caps prior to and during the measurements to ensure that the headspace of the monitoring wells was not diluted with air. The headspace of the wells was not purged prior to gas analysis in order to measure highest possible concentration. The gas phase of the wells was re-circulated at

$3881 \mathrm{l} / \mathrm{min}$ for 2 to 3 hours during measurements (i.e. approximately 2 to 3 times the volume of the headspace). Spectra were continuously recorded at a rate of 1 measurement per minute.

$390 \quad \mathrm{CO}_{2}, \mathrm{CH}_{4}$ and $\mathrm{N}_{2} \mathrm{O}$ measurements were performed during the period when the highest nitrate load was spiked in order to assess highest potential concentration of gases (see Figure 3).

\subsection{Denitrification performance of the PRB}

Figure 4 shows the performance of the $\mathrm{PRB}$ in removing $\mathrm{NO}_{3}^{-}$from groundwater. 

or, equivalently, at removal percentage $\geq 97 \%$. This meant that $\left[\mathrm{NO}_{3}^{-}\right] /\left[\mathrm{K}^{+}\right]$was lower

downgradient the PRB (MW2 and MW10) than upgradient (MW1 and MW9).

However, when $\mathrm{NO}_{3}{ }^{-}$concentration in feed barrels was increased to $20,000 \mathrm{mg} / \mathrm{L}$ from day 257 onwards, the DNF declined to $0.34\left(\mathrm{NO}_{3}{ }^{-}\right.$removal percentage of $\left.66 \%\right)$, making evident that the PRB has an ultimate design limit for $\mathrm{NO}_{3}{ }^{-}$load $(530 \mathrm{mg} / \mathrm{L}$ measured in the inlet gravel layer).

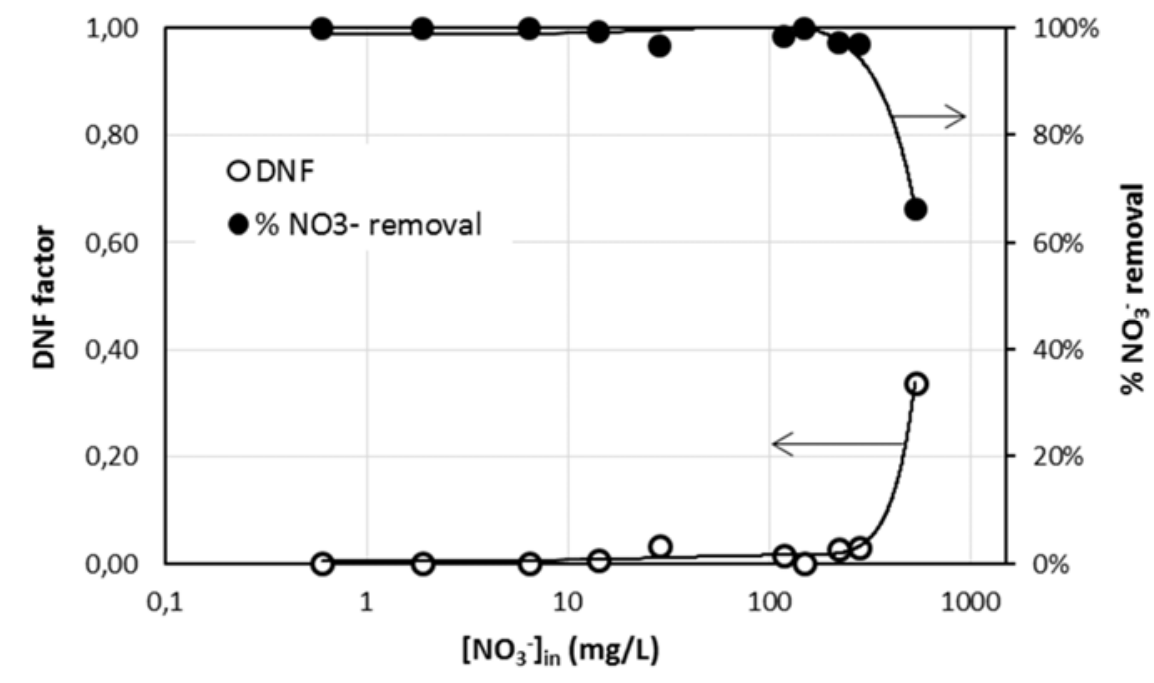

Figure 4: Denitrification factor (DNF) and $\mathrm{NO}_{3}{ }^{-}$removal percentage observed in the PRB as a function of $\mathrm{NO}_{3}{ }^{-}$concentration entering the PRB.

Three observations can be highlighted on the response of the PRB to the increase in the $\mathrm{NO}_{3}{ }^{-}$load:

First, the study period saw increasing severity of weather in Northern Ireland, resulting in near monthly flooding of the field by the River Braid and strong perturbations to the groundwater flow regime. This led to measured dilution factors in the upgradient gravel layer (mostly between 10 and 70) higher than that estimated during the tracer test (quantified at 10.8). Moreover, additional dilution (at factors 1-40) were occasionally observed within the PRB, 
433 likely due to lateral groundwater inputs during flooding. These dilutions factors resulted in $\mathrm{NO}_{3}{ }^{-}$

434 concentrations in the inlet of the PRB (between 0.6 and $530 \mathrm{mg} / \mathrm{L}$ ) that were up to 100 -fold

435 lower than the expected ones without the additional dilution. Although $\mathrm{K}^{+}$-normalized molar

436 ratio $\left[\mathrm{NO}_{3}^{-}\right] /\left[\mathrm{K}^{+}\right]$accounted for dilution effects and, thus, findings were not compromised by

437 them, for some campaigns, the low measured concentration of $\mathrm{K}^{+}$prevented reliable calculation

438 of DNF.

439 Second, neither $\mathrm{NO}_{2}^{-}$nor $\mathrm{NH}_{4}{ }^{+}$were detected in groundwater samples at relevant 440 concentrations (averaged concentrations of $0.5 \mathrm{mg} / \mathrm{L}$ and $0.3 \mathrm{mg} / \mathrm{L}$, respectively) throughout the 441 study, suggesting that most $\mathrm{NO}_{3}{ }^{-}$removal was due to denitrification and not through other 442 processes such as dissimilatory nitrate reduction to ammonia (DNRA). A possible $\mathrm{NO}_{3}{ }^{-}$removal 443 process that cannot be ruled out from the measurements taken alone is N-immobilization in 444 microbial biomass (Calderer et al., 2010). This process has been found of minor importance in 445 other denitrification PRBs (Schipper and Vojvodić-Vuković, 1998).

446 Third, DOC measured in groundwater from within the PRB exhibited a sustained 447 concentration in the range of $4-10 \mathrm{mg} / \mathrm{L}$ throughout the study (Figure 5), showing that mulch 448 was providing significantly increased level of DOC to sustain heterotrophic microbial activity. 449 An initial peak of up to $71 \mathrm{mg} / \mathrm{L}$ was measured in MW3, likely as a result of washout of organic 450 carbon. Similar high initial releases of DOC have also been observed in other denitrification 451 PRBs filled with natural organic substrates (Robertson and Cherry, 1995; Schipper and 452 Vojvodić-Vuković, 1998; Schmidt and Clark, 2012). 
Figure 5: Evolution of DOC in groundwater within the PRB at different depths (MW3 to MW5).

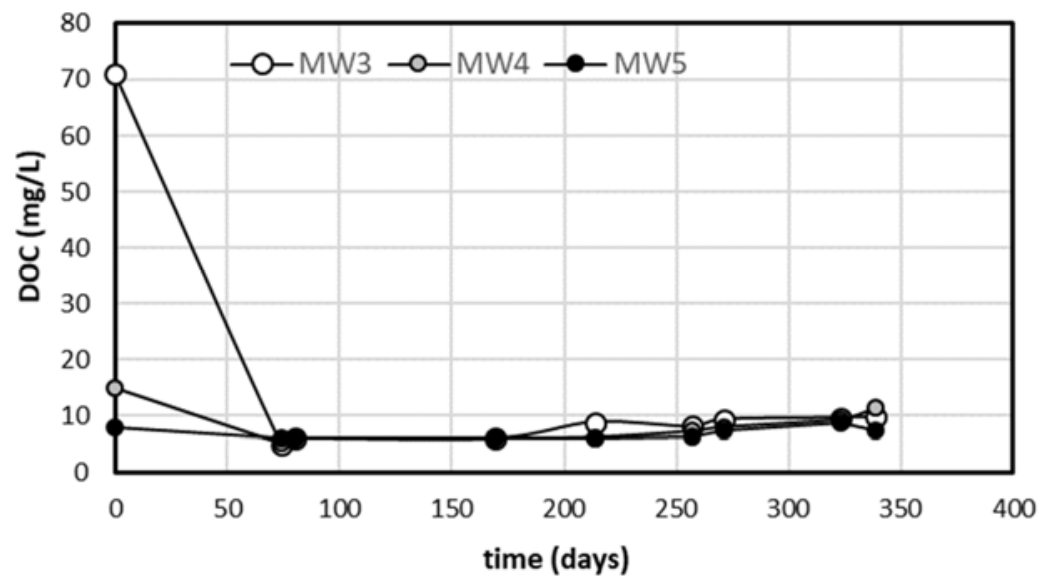
parameters (gravel to mulch ratio) where calculations showed it should be low enough to avoid both a negative impact on groundwater quality and undesirable processes like DNRA, but high enough to support heterotrophic denitrification activity. We should bear in mind here that other heterotrophic processes consuming DOC may inevitably also take place by other indigeneous microorganisms, such as aerobic respiration, sulphate-reduction and methanogenesis, as shown by the following equations, respectively: (reactions 2-5) were taking place in the PRB. This was further supported by the observed slight 
494 decreases of $\mathrm{pH}$ from inlet to outlet monitoring wells (averaged decreases of 0.3 units of $\mathrm{pH}$ ).

495 The occurrence of sulphate-reduction (reaction 4) in the PRB was evidenced by the observed 496 decrease of $\mathrm{K}^{+}$-normalised molar ratio $\left[\mathrm{SO}_{4}{ }^{2-}\right] /\left[\mathrm{K}^{+}\right]$, which averaged $30 \%$. Finally, analysis of

497 air in the headspace of the monitoring wells showed an enrichment in $\mathrm{CO}_{2}, \mathrm{CH}_{4}$ and $\mathrm{N}_{2} \mathrm{O}$ (see

498 below), indicating that eq. 3-5 were taking place.

499 Competition for $\mathrm{CH}_{2} \mathrm{O}$ between denitrifiers, aerobic degraders, methanogens and 500 sulphate-reducers should not be seen necessarily detrimental for denitrification to proceed, as it 501 is known that denitrifiers do not degrade complex polymeric carbon found in organic substrates 502 but depend on a consortium of miroorganisms to release more labile, simple organic compounds

503 (Schipper and Vojvodić-Vuković, 1998; Schipper and Vojvodić-Vuković, 2001). The synergies

504 in such a consortium was beyond the scope of this study, but it is likely that the co-occurrence 505 of reactions 2-5 helped denitrification to progress.

$506 \quad$ No change of the level of $\mathrm{NO}_{3}^{-}$in the river water between upstream and downstream of 507 the PRB was observed throughout the study. At all times, $\mathrm{NO}_{3}{ }^{-}$in the River Braid water ranged 508 between 11 and $16 \mathrm{mg} / \mathrm{L}$, and these measured concentrations were always higher than 509 concentrations measured in any of the monitoring wells between the PRB and the River Braid.

\section{3.2. Vertical profile of $\mathrm{NO}_{3}^{-}$within the $\mathrm{PRB}$}

512

Figure 6 illustrates $\mathrm{NO}_{3}^{-}$vertical profiles inside the PRB at different inlet $\mathrm{NO}_{3}^{-}$

515 generally declined downward from averaged values of 0.51 at depth $-2.0 \mathrm{~m}$ to 0.10 at depth -3.0

$516 \mathrm{~m}$. The greater $\mathrm{NO}_{3}{ }^{-}$removals at the bottom of the PRB can be justified by the fact that the

517 deeper the location the less atmospheric $\mathrm{O}_{2}$ intrusion and, therefore, the more reducing 518 conditions, which favours denitrification (Jahangir et al., 2012; Coco et al., 2018). 


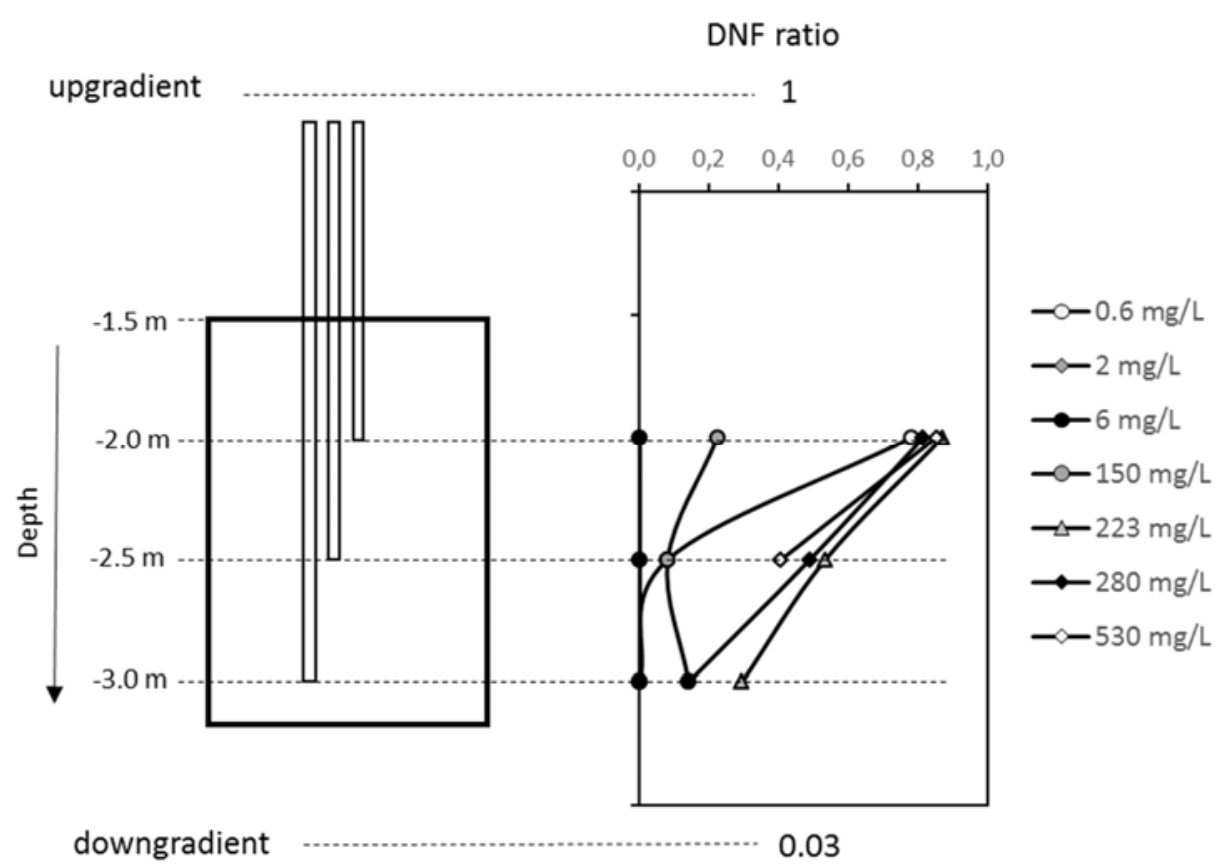

Figure 6: Vertical profiles of DNF within the PRB. Corresponding values for upgradient and downgradient the PRB are also shown

It must be underlined that DNF values shown in Figure 6 correspond to the monitoring wells in half of the PRB flow-distance. The overall $\mathrm{NO}_{3}{ }^{-}$removal was higher as groundwater travelled the whole width of the PRB (as shown in Figure 4).

\subsection{Gases analysis}

Emissions of generated $\mathrm{CO}_{2(\mathrm{~g})}, \mathrm{CH}_{4(\mathrm{~g})}$ and $\mathrm{N}_{2} \mathrm{O}_{(\mathrm{g})}$ from the PRB to the atmosphere can occur vertically via upward diffusion from groundwater through the unsaturated zone. Averaged emissions of $\mathrm{CO}_{2(\mathrm{~g})}, \mathrm{CH}_{4(\mathrm{~g})}$ and $\mathrm{N}_{2} \mathrm{O}_{(\mathrm{g})}$ measured from the closed chamber tests were 411.09 $\mathrm{mg} /\left(\mathrm{m}^{2} \cdot \mathrm{h}\right), 23.05 \mathrm{mg} /\left(\mathrm{m}^{2} \cdot \mathrm{h}\right)$ and $0.403 \mathrm{mg} /\left(\mathrm{m}^{2} \cdot \mathrm{h}\right)$, respectively (Table 2$)$. 
559

560

561

562

563

564

565

566

567

568

569

570

571

572

573

574

575

576

577

578

579

580

581

582

Flux of emitted gas

\begin{tabular}{lccc}
\cline { 3 - 4 } & & Average & st. dev. \\
\hline $\mathrm{CO}_{2}$ & $\mathrm{mg} /\left(\mathrm{m}^{2} \cdot \mathrm{h}\right)$ & 411.09 & 164.66 \\
$\mathrm{CH}_{4}$ & $\mathrm{mg} /\left(\mathrm{m}^{2} \cdot \mathrm{h}\right)$ & 23.05 & 3.99 \\
$\mathrm{~N}_{2} \mathrm{O}$ & $\mathrm{mg} /\left(\mathrm{m}^{2} \cdot \mathrm{h}\right)$ & 0.40 & 0.38 \\
\hline
\end{tabular}

Table 2: Emissions of generated $\mathrm{CO}_{2}, \mathrm{CH}_{4}$ and $\mathrm{N}_{2} \mathrm{O}$ from the $\mathrm{PRB}$ to the atmosphere measured from the closed chamber tests

The generation of $\mathrm{CO}_{2}, \mathrm{CH}_{4}$ and $\mathrm{N}_{2} \mathrm{O}$ was indicative of heterotrophic processes. $\mathrm{CO}_{2}$ can be formed from $\mathrm{HCO}_{3}{ }^{-}$as a product of reactions (2-5). $\mathrm{CH}_{4}$ reflected the prevalence of anaerobic conditions (at least in some parts) within the PRB, whereas $\mathrm{N}_{2} \mathrm{O}$ was indicative of (incomplete) denitrification.

There are no published studies that have examined gases emission from field-scale denitrification PRBs. However, the values obtained in this study compare well with other ecosystems under field conditions. In fact, $\mathrm{CO}_{2}$ emission fluxes were in the same order of magnitude as those measured in restored riparian wetlands $\left(353-732 \mathrm{mg} /\left(\mathrm{m}^{2} \cdot \mathrm{h}\right)\right.$ ) (Audet et al., 2013), constructed wetlands (32-489 $\left.\mathrm{mg} /\left(\mathrm{m}^{2} \cdot \mathrm{h}\right)\right)($ Søvik et al., 2006) and undisturbed natural soil (230-557 $\left.\mathrm{mg} /\left(\mathrm{m}^{2} \cdot \mathrm{h}\right)\right)$ (Yang et al., 2013), but considerably lower than those measured in some Danish agricultural peatlands (4033-5500 $\mathrm{mg} /\left(\mathrm{m}^{2} \cdot \mathrm{h}\right)$ ) (Elsgaard et al., 2012). $\mathrm{CH}_{4}$ emission fluxes were also comparable to those measured in wetlands $\left(4-49 \mathrm{mg} /\left(\mathrm{m}^{2} \cdot \mathrm{h}\right)\right)$ (Whalen, 2005; Audet et al., 2013), constructed wetlands $\left(1-47 \mathrm{mg} /\left(\mathrm{m}^{2} \cdot \mathrm{h}\right)\right)$ (Søvik et al., 2006) and undisturbed natural soil $\left(1-20 \mathrm{mg} /\left(\mathrm{m}^{2} \cdot \mathrm{h}\right)\right)$ (Yang et al., 2013), and much lower than those measured in landfills $\left(96 \mathrm{~g} /\left(\mathrm{m}^{2} \cdot \mathrm{h}\right)\right)$ (Bruun et al., 2017 and references therein). Finally, $\mathrm{N}_{2} \mathrm{O}$ flux values measured for the PRB fell in the lower end of values reported in literature in riparian soils $\left(0.02-31 \mathrm{mg} /\left(\mathrm{m}^{2} \cdot \mathrm{h}\right)\right)$ (Audet et al., 2013; Audet et al., 2014; Hinshaw and Dahlgren, 2016; Jurado et al., 2017 and references therein), European agricultural and forested ecosystems (0.4$\left.137 \mathrm{mg} /\left(\mathrm{m}^{2} \cdot \mathrm{h}\right)\right)\left(\right.$ Machfert et al., 2002) and constructed wetlands $\left(<0.01-58 \mathrm{mg} /\left(\mathrm{m}^{2} \cdot \mathrm{h}\right)\right)($ Søvik et al., 2006; Bruun et al., 2017). These values of $\mathrm{N}_{2} \mathrm{O}$ have been reported to not represent a 
significant contribution to the atmosphere compared to the direct emissions from agricultural

584 fields (Hinshaw and Dahlgren, 2016; Jurado et al., 2017). Taking into account the small area of the PRB (compared to other systems such as natural or constructed wetlands) it appears that the measured gas emissions in this study represent a minor contribution of total emissions to the atmosphere.

The low $\mathrm{CO}_{2}, \mathrm{CH}_{4}$ and $\mathrm{N}_{2} \mathrm{O}$ emissions do not necessarily imply that the concentrations of these gases in groundwater may not be high. It is well known that gases in groundwater can be over-saturated with respect to the overlying atmosphere (Jurado et al., 2017). $\mathrm{CO}_{2}, \mathrm{CH}_{4}$ and $\mathrm{N}_{2} \mathrm{O}$ concentrations in groundwater were not measured directly in the current study. However,

592 their content was measured in the headspace of the nested monitoring wells within the PRB.

593 Because these wells were filled with groundwater that entered through the screened zone at a 594 different depth, the content of gases in their headspace can be regarded as an indicator for microbial activity being active at different locations in the PRB. It must be bear in mind that these released gases do not diffuse through any soil layer (unlike those analysed in closed chamber tests), and thereby their contents are expected to the be higher than those measured in the closed chamber test.

Headspace gas within the three nested wells presented contents notably greater (for

$600 \mathrm{CH}_{4}$ ), greater (for $\mathrm{N}_{2} \mathrm{O}$ ) and only slightly greater (for $\mathrm{CO}_{2}$ ) than atmospheric background 601 (Figure 7). Contents varied depending on the depth of the monitoring well. $\mathrm{CO}_{2}$ contents were higher in the headspace of the shallowest piezometer, likely coming from aerobic respiration,

603 favoured in the upper part where diffusion of atmospheric $\mathrm{O}_{2}$ is not as limited as in deeper parts, 604 and to a lesser extent from denitrification and sulphate-reduction (which require much more 605 reducing conditions) (Stuart and Lapworth, 2016).

606 The opposite trend was exhibited by $\mathrm{N}_{2} \mathrm{O}$. Higher contents were seen in the deepest 607 piezometer while lower contents in the shallowest piezometer. This was consistent with the 608 DNF vertical profile showing that it is in the deepest part where denitrification is favoured. 609 Degassing of $\mathrm{N}_{2} \mathrm{O}$ generated in the deepest part to the atmosphere is often hindered by 1) the 610 low $\mathrm{N}_{2} \mathrm{O}$ diffusivity through saturated soil (the diffusion coefficient of $\mathrm{N}_{2} \mathrm{O}$ in water is around 
611 four orders of magnitude smaller than in air), which makes that the larger the water column

612 above a location the lower the amount released to the atmosphere (Heincke and Kaupenjohann,

613 1999) and 2) the microbial reduction of $\mathrm{N}_{2} \mathrm{O}$ to $\mathrm{N}_{2}$ during the slow upward diffusion (Jahangir et

614 al., 2012; Jurado et al., 2017; Cocco et al., 2018).

615 No specific pattern was observed with regard to $\mathrm{CH}_{4}$. More measurements should be 616 done to elucidate whether $\mathrm{CH}_{4}$ differs between monitoring wells at different depths.

617

618

619

620

621

622

623

624

625

626

627

628

629

630

631

632

633

634

635

636

637

638

639

640

641

642

643

644

645

646

647

648

649
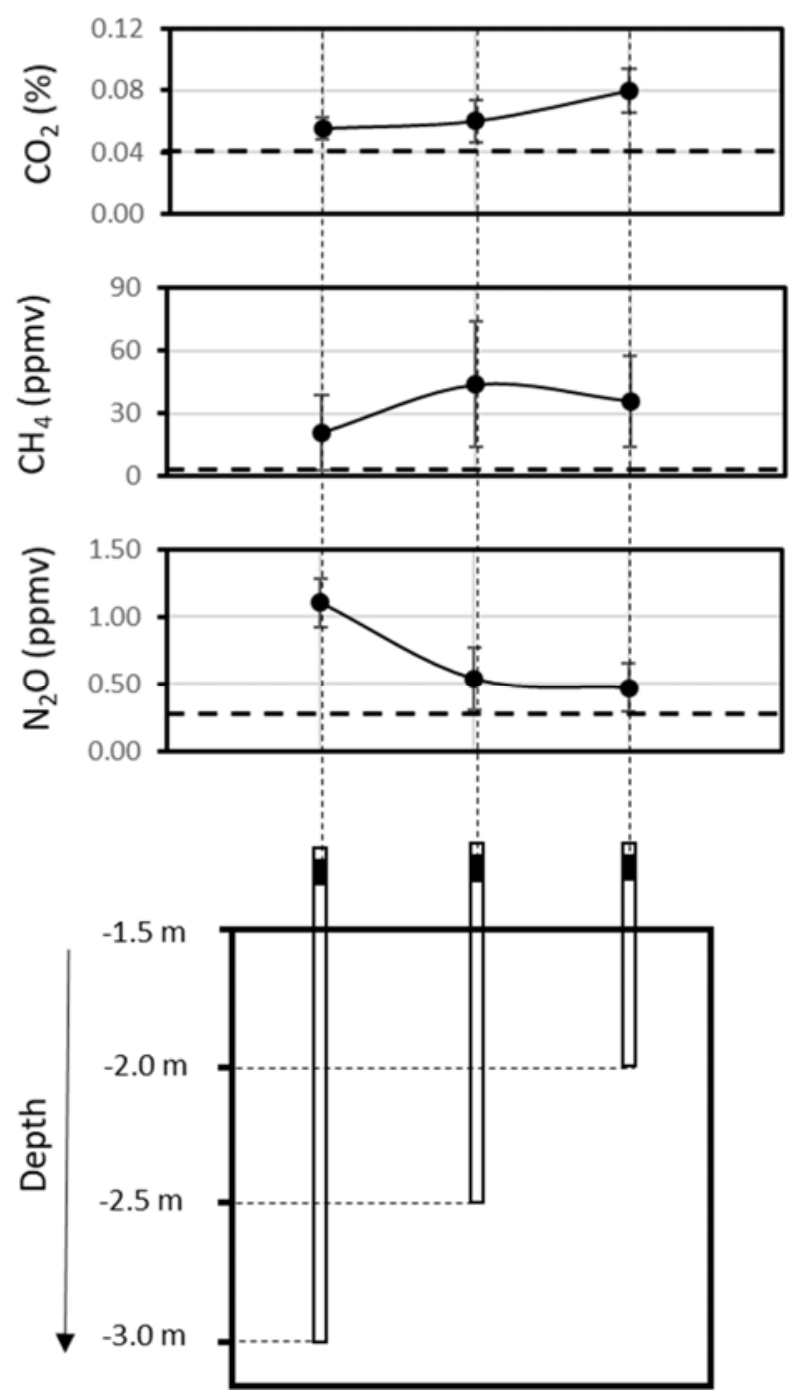

Figure 7: Contents of $\mathrm{CO}_{2}, \mathrm{CH}_{4}$ and $\mathrm{N}_{2} \mathrm{O}$ in the headspace of the nested wells at three different depths within the PRB. The dashed horizontal lines delineate the atmospheric background levels of $\mathrm{CO}_{2}, \mathrm{CH}_{4}$ and $\mathrm{N}_{2} \mathrm{O}$. 

as reported in peer-reviewed journals. Four of these are in Canada and USA and two in Australia and New Zealand. This is, thus, the first PRB of this type in Europe. Table 3 presents an inventory of these denitrification PRBs, together with the one reported here, to facilitate comparisons among them. The principles and design of all them are comparable in general terms. The one reported here is singular in that it is the only one with a $\mathrm{NO}_{3}{ }^{-}$delivery system. hydraulic points of view. From a chemical point of view, all reported PRBs demonstrate that denitrification can satisfactorily be promoted in the subsurface by means of a natural solid organic substrate (sawdust, woodchips, mulch). In all cases, $\mathrm{NO}_{3}^{-}$removal within the PRB was

663 found $>70 \%$ (with inlet $\mathrm{NO}_{3}{ }^{-}$inputs ranging between $2-438 \mathrm{mg} / \mathrm{L}$ ) and the main $\mathrm{NO}_{3}{ }^{-}$removal 664 mechanism was identified to be heterotrophic denitrification, promoted by the release of DOC 665 from the solid natural organic substrate. For two of the PRBs, authors have estimated that, based on the release rate of DOC, the denitrification capacity can be maintained for many decades

667 (Schipper and Vojvodić-Vuković, 2001; Robertson et al., 2008; Long et al., 2011). In some 668 PRBs, denitrification has been confirmed by monitoring denitrification enzyme activity (DEA) 669 (Schipper and Vojvodić-Vuković, 2001; Schipper et al., 2004; Schmidt and Clark, 2012) or by 670 means of microbiological tools (Hiller et al., 2015). Residence time $\left(t_{R}\right)$ within these 671 denitrification PRBs ranges from 1.8-13 days (based on the explicitly reported values), which 672 indicates that denitrification is a faster process than sulphate-reduction, for which $t_{R}$ required in 673 a PRB is in the order of (at least) 90 days to satisfactorily take place (Benner et al., 2002; Gibert 674 et al., 2011).

675 However, it is from hydrogeological perspective that some of these documented PRB 676 show their flaws. In fact, it is not rare that PRBs suffer from unforeseen changes in groundwater 677 directions and/or improper hydraulic characterization of the site prior to PRB installation, which 
678 results in limited capture of the $\mathrm{NO}_{3}{ }^{-}$-contaminated plume, diversion and/or partial or total by679 pass of the groundwater around the PRB. Fluctuations of groundwater flow rates (with up to 25680 fold decreases) or even bypasses around the PRB depending on the season have been reported 681 for four of the six reported denitrifying PRBs (Schipper and Vojvodić-Vuković, 2000; Schipper 682 et al., 2004; Robertson et al., 2008; Schmidt and Clark, 2012). Design flaws on the site 683 characterization with the subsequent loss of hydraulic control have been reported to be the most 684 common cause of PRB failures (Henderson and Demond 2007), especially when climatic 685 conditions can vary considerably over the year and so do the aquifer hydrologic conditions, in 686 particular following heavy and sustained rainfalls. 


\begin{tabular}{|c|c|c|c|c|c|c|c|c|c|c|c|c|}
\hline \multirow[t]{2}{*}{ Location } & \multirow[t]{2}{*}{ Dimensions } & \multirow[t]{2}{*}{ Composition } & \multirow[t]{2}{*}{$t_{R}(d)$} & \multicolumn{4}{|c|}{$\left[\mathrm{NO}_{3}{ }^{-}\right](\mathrm{mg} / \mathrm{L})$} & \multicolumn{3}{|c|}{$[\mathrm{DOC}](\mathrm{mg} / \mathrm{L})$} & \multirow[t]{2}{*}{ Hydraulic performance } & \multirow[t]{2}{*}{ Reference } \\
\hline & & & & $\begin{array}{c}\text { up- } \\
\text { gradient }\end{array}$ & $\begin{array}{l}\text { in the } \\
\text { PRB }\end{array}$ & $\begin{array}{l}\text { down- } \\
\text { gradient }\end{array}$ & $\begin{array}{l}\text { removal } \\
\text { up-down }\end{array}$ & $\begin{array}{c}\text { up- } \\
\text { gradient }\end{array}$ & $\begin{array}{l}\text { in the } \\
\text { PRB }\end{array}$ & $\begin{array}{l}\text { down- } \\
\text { gradient }\end{array}$ & & \\
\hline $\begin{array}{l}\text { Long Point, } \\
\text { Ontario, } \\
\text { Canada }\end{array}$ & $\begin{array}{l}\mathrm{L}=\mathrm{n} . \mathrm{r} . \\
\mathrm{D}=1.2 \mathrm{~m} \\
\mathrm{~T}=0.6 \mathrm{~m}\end{array}$ & $\begin{array}{l}\text { Soil }(80 \%) \\
\text { Sawdust } \\
(20 \%)\end{array}$ & $10-13$ & $106-283$ & n.d. & $9-111$ & $72-97 \%$ & $2.9-5.7$ & & $4.4-5.6$ & $\begin{array}{l}\text { Difficulties in intercepting } \\
\text { the contaminated plume, } \\
\text { causing dilution with } \\
\text { uncontaminated groundwater } \\
\text { within the PRB }\end{array}$ & $\begin{array}{l}\text { Robertson and Cherry, } 1995 \\
\text { Robertson et al., 2000; } 2008\end{array}$ \\
\hline $\begin{array}{l}\text { Cambridge, } \\
\text { North Island, } \\
\text { New Zealand }\end{array}$ & $\begin{array}{l}\mathrm{L}=35 \mathrm{~m} \\
\mathrm{D}=1.5 \mathrm{~m} \\
\mathrm{~T}=1.5 \mathrm{~m}\end{array}$ & $\begin{array}{l}\text { Soil }(70 \%) \\
\text { Sawdust } \\
(30 \%)\end{array}$ & $\begin{array}{l}\text { "several } \\
\text { days" }\end{array}$ & $22-71$ & $\begin{array}{l}2.7- \\
8.8\end{array}$ & $<8.8$ & $70-95 \%$ & & & & $\begin{array}{l}\text { Difficulties in intercepting } \\
\text { the plume, "because the } \\
\text { majority of the sampled } \\
\text { groundwater had flowed } \\
\text { beneath the wall". }\end{array}$ & $\begin{array}{l}\text { Schipper and Vojvodić- } \\
\text { Vuković, 1998; 2000; } 2001 . \\
\text { Long et al., } 2011\end{array}$ \\
\hline $\begin{array}{l}\text { Cambridge, } \\
\text { North Island, } \\
\text { New Zealand }\end{array}$ & $\begin{array}{l}\mathrm{L}=40 \\
\mathrm{D}=3.0 \mathrm{~m} \\
\mathrm{~T}=3.0 \mathrm{~m}\end{array}$ & $\begin{array}{l}\text { Soil }(80 \%) \\
\text { Sawdust } \\
(20 \%)\end{array}$ & n.r. & $93-173$ & 0.9 & $84-194$ & $\approx 0 \%$ & n.d. & n.d. & n.d. & $\begin{array}{l}\text { Difficulties in intercepting } \\
\text { the plume, as "most of the } \\
\text { groundwater flowed under } \\
\text { rather than through the } \\
\text { wall". }\end{array}$ & Schipper et al., 2004 \\
\hline $\begin{array}{l}\text { Zorra, } \\
\text { Ontario, } \\
\text { Canada }\end{array}$ & $\begin{array}{l}\mathrm{L}=8 \mathrm{~m} \\
\mathrm{D}=0.5 \mathrm{~m} \\
\mathrm{~T}=4.0 \mathrm{~m}\end{array}$ & $\begin{array}{l}\text { Sediment } \\
\text { Wood particle }\end{array}$ & 13 & $27-438$ & 31 & 23 & $90 \%$ & 3.5 & 667 & 330 & None reported & Robertson et al., 2007 \\
\hline $\begin{array}{l}\text { Waquoit Bay, } \\
\text { Falmouth, } \\
\text { Massachussets } \\
\text { (USA) }\end{array}$ & $\begin{array}{l}\mathrm{L}=20 \mathrm{~m} \\
\mathrm{D}=2.5 \mathrm{~m} \\
\mathrm{~T}=3.7 \mathrm{~m}\end{array}$ & Woodchips & n.r. & 2 & $<$ d.l. & $<$ d.l. & $>99 \%$ & 0.7 & 1.4 & & None reported & Hiller et al., 2015 \\
\hline $\begin{array}{l}\text { Alachua, } \\
\text { Florida (USA) }\end{array}$ & $\begin{array}{l}\mathrm{L}=55 \mathrm{~m} \\
\mathrm{D}=1.8 \mathrm{~m} \\
\mathrm{~T}=1.7 \mathrm{~m}\end{array}$ & $\begin{array}{l}\text { Sand }(50 \%) \\
\text { Sawdust } \\
(50 \%)\end{array}$ & 1.8 & 27 & & 7 & $77 \%$ & 2 & 34 & 70 & $\begin{array}{l}\text { Some "groundwater } \\
\text { bypassing the edge of the } \\
\text { wall" }\end{array}$ & Schmidt and Clark, 2012 \\
\hline $\begin{array}{l}\text { Ballymena, } \\
\text { Northern Ireland, } \\
\text { United Kingdom }\end{array}$ & $\begin{array}{l}\mathrm{L}=20 \mathrm{~m} \\
\mathrm{D}=1.7 \mathrm{~m} \\
\mathrm{~T}=1.2 \mathrm{~m}\end{array}$ & $\begin{array}{l}\text { Gravel (50\%) } \\
\text { Mulch (50\%) }\end{array}$ & $\begin{array}{c}14 \\
\text { (variable) }\end{array}$ & $0.6-530$ & $\begin{array}{c}<\text { d.1.- } \\
182\end{array}$ & $<$ d.1.-29 & $66-99 \%$ & $1-3$ & $4-10$ & $4-7$ & $\begin{array}{l}\text { Occasional lateral } \\
\text { groundwater inputs resulting } \\
\text { in dilution within the PRB }\end{array}$ & This study \\
\hline
\end{tabular}

$\mathrm{L}=$ length, $\mathrm{D}=$ depth, $\mathrm{T}=$ thickness

d.1.: detection limit, n.r.: not reported

Table 3: Compilation of the existing biological PRBs for the treatment of $\mathrm{NO}_{3}^{-}$-contaminated groundwater worldwide . 


\section{4. CONCLUSIONS}

3 The conclusions of the study can be summarised as follows:

5 - The denitrification PRB was successful at removing $\mathrm{NO}_{3}^{-}$from groundwater at inlet 6 concentrations up to $280 \mathrm{mg} / \mathrm{L}$ (with $\mathrm{NO}_{3}^{-}$removal percentages $\geq 97 \%$ ). When $\mathrm{NO}_{3}^{-}$ 7 concentration was $530 \mathrm{mg} / \mathrm{L}$ the $\mathrm{NO}_{3}{ }^{-}$removal percentage declined to $66 \%$. To reliably attribute 8 any decrease of $\mathrm{NO}_{3}{ }^{-}$concentration to $\mathrm{NO}_{3}{ }^{-}$removal, its concentration was normalized with 9 respect to a conservative ion $\left(\mathrm{K}^{+}\right)$also spiked with $\mathrm{NO}_{3}^{-}$(as $\mathrm{KNO}_{3}$ ) to account for possible 10 dilution effects.

11 - The marginal levels of $\mathrm{NO}_{2}^{-}$and $\mathrm{NH}_{4}{ }^{+}$indicated that $\mathrm{NO}_{3}{ }^{-}$removal was mainly through 12 denitrification and not through other processes such as DNRA.

13 - Monitoring groundwater at different depths within the PRB provided evidence that $\mathrm{NO}_{3}{ }^{-}$ 14 underwent denitrification preferably at the deepest part of the PRB (removals mostly $>60 \%$ ), 15 where more favourable reducing conditions were achieved. The higher contents of $\mathrm{N}_{2} \mathrm{O}_{(\mathrm{g})}$ measured in the headspace of the deeper monitoring well seemed to confirm this trend.

- The analysis of other dissolved ion species $\left(\mathrm{SO}_{4}{ }^{2-}\right)$ and gases $\left(\mathrm{CO}_{2}, \mathrm{CH}_{4}\right)$ revealed that heterotrophic processes other than denitrification were also active within the PRB. These processes included aerobic respiration, sulphate-reduction and methanogenesis.

- The intense rainfalls during the operation period of the PRB resulted in greater $\mathrm{NO}_{3}{ }^{-}$

21 dilutions than expected from the initial site hydrogeological characterisation. Although this additional dilution did not pose concern for the denitrification capacity of the PRB, for some campaigns the low concentration of the conservative ion $\mathrm{K}^{+}$prevented reliable calculation of 24 denitrification removal percentage.

- Emission fluxes of $\mathrm{CO}_{2}, \mathrm{CH}_{4}$ and $\mathrm{N}_{2} \mathrm{O}$ were comparable with other ecosystems under

26 field conditions. Because of the small area covered by the PRB, these fluxes do not represent 
1 any significant contribution to greenhouse gases to the atmosphere. Further work is required on

2 this field.

3

5 CONFLICTS OF INTEREST

6

7 The authors declare no conflict of interests.

\section{ACKNOWLEDGEMENTS}

We thank the Northern Ireland Environment Agency and the Scottish Research

13 Partnership in Engineering for its willingness to work with the project as well as the Ecos

14 Centre and the Ballymena Borough Council (Northern Ireland) for their financial and

15 operational support. We also acknowledge Ecomesh Ltd for its cooperation throughout the

16 project. The project was funded by the European Community under the LIFE program (LIFE05

$17 \mathrm{ENV/UK} / 000137)$.

18

19

20

21

22

23

24

25

26

27

28

29

30

31

32

33

\section{REFERENCES}

Addy, K., Gold, A.J., Christianson, L.E., David M.B., Schipper, L.A., Ratigan, N.A., 2016. Denitrifying bioreactors for nitrate removal: a meta-analysis. J. Environ. Qual. 45, 873-881.

https://doi:10.2134/jeq2015.07.0399

APHA (American Public Health Association), 1999. Standard Methods for the Examination of Water and Wastewater, 20th ed.; American Water Works Association (AWWA), Water Pollution Control Federation: Washington, DC.

Audet, J., Elsgaard, L., Kjaergaard, C., Larsen, S.E., Hoffmann, C.C., 2013. Greenhouse gas emissions from a Danish riparian wetland before and after restoration. Ecol. Eng. 57, 170- 182. http://dx.doi.org/10.1016/j.ecoleng.2013.04.021 
1 Audet, J., Hoffmann, C.C., Andersen, P.M., Baattrup-Pedersen, A., Johansen, J.R., Larsen, S.E.,

2 Kjaergaard, C., Elsgaard, L., 2014. Nitrous oxide fluxes in undisturbed riparian wetlands

3 located in agricultural catchments: emission, uptake and controlling factors. Soil Biol. Biochem.

4 68, 291-299. http://dx.doi.org/10.1016/j.soilbio.2013.10.011

5

6 Benner, S.G., Blowes, D.W., Ptacek, C.J., Mayer, K.U., 2002. Rates of sulfate reduction and

7 metal sulfide precipitation in a permeable reactive barrier. Appl. Geochem. 17, 301-320.

$8 \quad$ http://doi:10.1016/S0883-2927(01)00084-1

Bruun, J., Hoffmann, C.C., Kjaergaard, C., 2017. Convective transport of dissolved gases determines the fate of the greenhouse gases produced in reactive drainage filters. Ecol. Eng. 98, 1-10. http://dx.doi.org/10.1016/j.ecoleng.2016.10.027

BSI (British Standards Institution), 1984. Water quality. Physical, chemical and biochemical methods. Determination of ammonium: manual spectrometric method; London, U.K..

Calderer, M., Gibert, O., Martí, V., Rovira, M., de Pablo, J., Jordana, S., Duro, L., Guimerà, J., Bruno, J., 2010. Denitrification in presence of acetate and glucose for bioremediation of nitratecontaminated groundwater. Environ. Technol. 31, 799-814. http://dx.doi.org/10.1080/09593331003667741

Capodici, M., Avona, A., Laudicina, V.A., Viviani, G. 2018. Biological groundwater denitrification systems: Lab-scale trials aimed at nitrous oxide production and emission assessment. Sci. Total Environ. 630, 462-468. https://doi.org/10.1016/j.scitotenv.2018.02.260

Cocco, E., Bertora, C., Squartini, A., Delle Vedove, G., Berti, A., Grignani, C., Lazzaro, B., Morari, F., 2018. How shallow water table conditions affect $\mathrm{N}_{2} \mathrm{O}$ emissions and associated microbial abundances under different nitrogen fertilisations. Agr. Ecosyst. Environ. 261, 1-11. https://doi.org/10.1016/j.agee.2018.03.018

Della Rocca, C., Belgiorno, V., Meriç, S., 2007. Overview of in-situ applicable nitrate removal processes. Desalination 204, 46-62. https://doi:10.1016/j.desal.2006.04.023

Elsgaard, L., Görresa, C.-M., Hoffmann, C.C., Blicher-Mathiesen, G., Schelde, K., Petersen, S.O., 2012. Net ecosystem exchange of $\mathrm{CO}_{2}$ and carbon balance for eight temperate organic soils under agricultural management. Agr. Ecosyst. Environ. 162, 52- 67. http://dx.doi.org/10.1016/j.agee.2012.09.001

Fazal, A., Imaizumi, M., Ishida, S., Kawachi, T., Tsuchihara, T., Takeuchi, J., Alam, A.H.M.B., 2003. Review on groundwater nitrate contamination: causes, effects and remedies $-\mathrm{A}$ guideline for efficient management strategy. J. Rainwat. Catch. Syst. 8, 15-33. https://doi.org/10.7132/jrcsa.KJ00000795202 
1 Gavaskar, A.R., 1999. Design and construction techniques for permeable reactive barriers. J.

2 Hazard. Mater. 68, 41-71. http://doi:10.1016/S0304-3894(99)00031-x

3

4 Gibert, O., Ferguson, A.S., Kalin, R. M., Doherty, R., Dickson, K.W., McGeough, K.L.,

5 Robinson, J., Thomas, R., 2007. Performance of a sequential reactive barrier for bioremediation

6 of coal tar contaminated groundwater. Environ. Sci. Technol. 41, 6795-6801.

7 http://doi:10.1021/es071527f

8

9 Gibert, O., Pomierny, S., Rowe, I., Kalin, R.M., 2008. Selection of organic substrates as

10 potential reactive materials for use in a denitrification permeable reactive barrier (PRB).

11 Bioresource Technol. 99, 7587-7596. http://doi:10.1016/j.biortech.2008.02.012

Gibert, O., Rötting, T., Cortina, J.L., de Pablo, J., Ayora, C., Carrera, J., Bolzicco, J., 2011. Insitu remediation of acid mine drainage using a permeable reactive barrier in Aznalcóllar ( $\mathrm{Sw}$ Spain). J. Hazard. Mater. 191, 287-295. http://doi:10.1016/j.jhazmat.2011.04.082

Gibert, O., Cortina, J.L., de Pablo, J., Ayora, C., 2013. Performance of a field-scale permeable reactive barrier based on organic substrate and zero-valent iron for in situ remediation of acid mine drainage. Environ. Sci. Pollut. Res. 20, 7854-7862. http://doi:10.1007/s11356-013-1507-2

Heincke, M., Kaupenjohann, M., 1999. Effects of soil solution on the dynamics of $\mathrm{N}_{2} \mathrm{O}$

emissions: a review. Nutr. Cycl. Agroecosys. 55, 133-157.

23 http://doi:10.1023/A:1009842011599

Hensen, A., Skiba, U., Famulari, D., 2013. Low cost and state of the art methods to measure

Henderson, A.D., Demond, A.H., 2007. Long-term performance of zero-valent iron permeable reactive barriers: a critical review. Environ. Eng. Sci. 24, 401-423.

http://doi:10.1089/ees.2006.0071 nitrous oxide emissions. Environ. Res. Lett. 8, 1-10. http://doi:10.1088/1748-9326/8/2/025022

Hiller, K.A., Foreman, K.H., Weisman, D., Bowen, J.L., 2015. Permeable reactive barriers designed to mitigate eutrophication alter bacterial community composition and aquifer redox conditions. Appl. Environ. Microb. 81, 7114-7124. http://doi:10.1128/AEM.01986-15

Hinshaw, S.E., Dahlgren, R.A., 2016. Nitrous oxide fluxes and dissolved $\mathrm{N}$ gases $\left(\mathrm{N}_{2}\right.$ and $\left.\mathrm{N}_{2} \mathrm{O}\right)$ within riparian zones along the agriculturally impacted San Joaquin River. Nutr. Cycl. Agroecosyst. 105, 85-102. https://doi:10.1007/s10705-016-9777-y

Huang, G., Huang, Y., Hud, H., Liu, F., Zhang, Y., Deng, R., 2015. Remediation of nitratenitrogen contaminated groundwater using a pilot-scale two-layer heterotrophic-autotrophic 42 denitrification permeable reactive barrier with spongy iron/pine bark. Chemosphere 130, 8-16. 43 http://dx.doi.org/10.1016/j.chemosphere.2015.02.029 
2 IPCC (Intergovernmental Panel on Climate Change), 2007. Fourth Assessment Report: Climate

3 Change 2007. Cambridge University Press, Cambridge.

4

Jahangir, M.M.R., Khalil, M.I., Johnston, P., Cardenas, L.M., Hatch, D.J., Butler, M., Barrett, M., O'Flaherty, V., Richards, K.G., 2012. Denitrification potential in subsoils: A mechanism to

7 reduce nitrate leaching to groundwater. Agr. Ecosyst. Environ. 147, 13- 23.

8 https://doi:10.1016/j.agee.2011.04.015

Jurado, A., Borges, A.V., Brouyère, S., 2017. Dynamics and emissions of $\mathrm{N}_{2} \mathrm{O}$ in groundwater:

$\begin{array}{lllll}\text { a } & \text { review. } & \text { Sci. } & \text { Total } & \text { Environ. }\end{array}$

http://dx.doi.org/10.1016/j.scitotenv.2017.01.127

Kalin, R.M., 2004. Engineered passive bioreactive barriers: risk-managing the legacy of industrial soil and groundwater pollution. Curr. Opin. Microbiol. 2004, 7, 227-238. http://doi:10.1016/j.mib.2004.04.014

Li, T., Li, W., Feng, C., Hu, W., 2017. In-situ biological denitrification using pretreated maize stalks as carbon source for nitrate-contaminated groundwater remediation. Water Sci. Technol. 17: 1-9. https://doi:10.2166/ws.2016.096

Long, L.M., Schipper, L.A., Bruesewitz, D.A., 2011. Long-term nitrate removal in a denitrification wall. Agr. Ecosyst. Environ. 140, 514-520.

Machfert, S.E., Dise, N.B., Goulding, K.W.T., Whitehead, P.G., 2002. Nitrous oxide emission from a range of land uses across Europe. Hydrol. Earth Syst. Sci. 6, 325-338.

https://doi.org/10.5194/hess-6-325-2002

McGovern, T., Guerin, T. F., Horner, S., Davey, B., 2002. Design, construction and operation of

Obiri-Nyarko, F., Grajales-Mesa S.J., Malina, G., 2014. An overview of permeable reactive https://doi.org/10.1016/j.chemosphere.2014.03.112 
1 Robertson, W.D., Cherry, J.A., 1995. In situ denitrification of septic-system nitrate using

2 reactive porous media barriers: field trials. Ground Water 33, 99-111.

3 https://doi.org/10.1111/j.1745-6584.1995.tb00266.x

4

Robertson, W.D., Blowes, D.W., Ptacek, C.J., Cherry, J.A., 2000. Long-term performance of in situ reactive barriers for nitrate remediation. Ground Water 38, 689-695. https://doi.org/10.1111/j.1745-6584.2000.tb02704.x

Robertson, W.D., Ptacek, C.J., Brown, S.J., 2007. Geochemical and hydrogeological impacts of 10 a wood particle barrier treating nitrate and perchlorate in ground water. Ground Water Monit. R.

Robertson, W.D., Vogan, J.L., Lombardo, P.S., 2008. Nitrate removal rates in a 15-year-old permeable reactive barrier treating septic system nitrate. Ground Water Monit. R. 28, 65-72. https://doi.org/10.1111/j.1745-6592.2008.00205.x

Scherer, M.M.S., Richter, S., Valentine, R.L., Alvarez, P.J.J., 2000. Chemistry and microbiology of reactive barriers for in situ groundwater cleanup, Crit. Rev. Environ. Sci. Technol. 30, 363-411. http://doi:10.1080/10408410091154237

Schipper, L.A., Vojvodić-Vuković, M., 1998. Nitrate removal from groundwater using a denitrification wall amended with sawdust: field trial. J. Environ. Qual. 27, 664-668. http://doi:10.2134/jeq1998.00472425002700030025x

Schipper, L.A., Vojvodić-Vuković, M., 2000. Nitrate removal from groundwater and denitrification rates in a porous treatment wall amended with sawdust. Ecol. Eng. 14, 269-278. http://dx.doi.org/10.1016/S0925-8574(99)00002-6

Schipper, L.A., Vojvodić-Vuković, M., 2001. Five years of nitrate removal, denitrification and carbon dynamics in a denitrification wall. Water Res. 35, 3473-3477. http://doi:10.1016/S0043$\underline{1354(01) 00052-5}$

Schipper, L.A., Barkle, G.F., Hadfield, J.C., Vojvodić-Vuković, M., Burgess, C.P., 2004.

34 Hydraulic constraints on the performance of a groundwater denitrification wall for nitrate 35 removal from shallow groundwater. J. Contam. Hydrol. 69, 263-279. http://doi:10.1016/S0169$36 \quad \underline{7722(03) 00157-8}$

38 Schmidt, C.A., Clark, M.W., 2012. Efficacy of a denitrification wall to treat continuously high 39 nitrate loads. Ecol. Eng. 42, 203-211. http://doi:10.1016/j.ecoleng.2012.02.006

41 Søvik, K., Augustin, J., Heikkinen, K., Huttunen, J. T., Necki, J.M., Karjalainen, S.M., Kløve, 42 B., Liikanen, A., Mander, Ü., Puustinen, M., Teiter, S., Wachniew, P., 2006. Emission of the 
1 greenhouse gases nitrous oxide and methane from constructed wetlands in Europe. J. Environ.

2 Qual. 35, 2360-2373. http://doi:10.2134/jeq2006.0038

3

4 Stuart, M.E., Lapworth, D.J. 2016. Macronutrient status of UK groundwater: Nitrogen, 5 phosphorus and organic carbon. Sci. Total Environ. 572, 1543-1560.

6 http://dx.doi.org/10.1016/j.scitotenv.2016.02.181

7

8 Su, C., Puls, R.W., 2006. Removal of added nitrate in cotton burr compost, mulch compost, and

9 peat: mechanisms and potential use for groundwater nitrate remediation. Chemosphere 66, 91-

10 98. http://doi:10.1016/j.chemosphere.2006.05.015

11

12 USEPA (U.S. Environmental Protection Agency) 1983. Methods for Chemical Analysis of 13 Water and Wastes, Environmental Monitoring and Support Laboratory; Office of Research and 14 Development, U.S. EPA: Cincinnati, OH.

15

16 Whalen, S.C., 2005. Biogeochemistry of methane exchange between naturalwetlands and the 17 atmosphere. Environ. Eng Sci. 22, 73-94. https://doi.org/10.1089/ees.2005.22.73

18

19 Yang, J., Liu, J., Hua, X., Li, X., Wang, Y., Li, H., 2013. Effect of water table level on $\mathrm{CO}_{2}$, $20 \mathrm{CH}_{4}$ and $\mathrm{N}_{2} \mathrm{O}$ emissions in a freshwater marsh of Northeast China. Soil Biol. Biochem. 61, 5221 60. http://dx.doi.org/10.1016/j.soilbio.2013.02.009 